\title{
NOVOS CONTORNOS DA GESTÃO LOCAL: CONCEITOS EM CONSTRUÇÃO
}

\author{
Por Ricardo Bresler \\ Professor do Departamento de Administração Geral e Recursos Humanos (ADM) da FGV-EAESP. \\ E-mail: rbresler@fgvsp.br
}

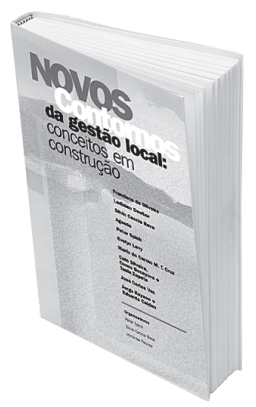

\section{NOVOS CONTORNOS DA GESTÃO} LOCAL: conceitos em construção

De Peter Spink, Silvio Caccia Bava e Veronika Paulics (Orgs.)

São Paulo : Instituto Pólis \& Programa Gestão Pública e Cidadania (FGV-EAESP), 2002. 336 p.
Pode ser novidade para quem busca construções teóricas que partam da realidade. Pode ser novidade para quem acha que a gestão pública continua sendo sinônimo de ineficiência, marasmo, corrupção, palco para práticas clientelistas e que visam ao favorecimento de interesses privados. Nessa visão, nada teríamos feito para superar o Estado patrimonialista.

Se, por um lado, avançamos no diagnóstico das causas e nefastas conseqüências do Estado privatizado, por outro, fomos expostos a inúmeras representações do Estado como inimigo da sociedade que, direta ou indiretamente, se afiliam às pregações neoliberais. Para os leigos, essa mensagem chegou com mais impacto. Para alguns - representantes e servidores públicos, lideranças comunitárias, pesquisadores -, o desenvolvimento da crítica semeou condições para efetivar outras práticas.

Desde os anos 1980, diversos gestores municipais revertem o quadro de esfacelamento do público, voltando-se para as demandas da população, im- plantando inovações que promovem a transparência, os mecanismos de autoridade e o aprofundamento da democracia. Com a Constituição de 1988 essas práticas ganharam espaço e legitimidade para se efetivarem. A partir daí, acelerou-se o processo de práticas inovadoras em gestão local.

No final do mandato dos primeiros prefeitos eleitos após a nova Constituição, as soluções encontradas para lidar com as demandas da sociedade começaram a chamar a atenção. O Instituto Pólis (www.polis.org.br), a partir de sua inserção em redes, sistematizou 51 experiências inovadoras (Nogueira, Simões Jr. e Almeida, Experiências Inovadoras em Gestão Municipal, 1992). Com a repercussão do texto e o apoio da Fundação Friedrich Ebert (www.fes.org.br), foi criado o boletim Dicas - Idéias para a Ação Municipal, que, por meio de textos curtos, dissemina práticas que promovem a democracia. Em 2000, com o apoio do BNDES, o Pólis publicou o livro 125 Dicas, cujos textos estão no Banco Federativo (http:// federativo.bndes.gov.br/dicas). Em maio de 2003 foi lançado o Dicas n² 200, sobre Escola de Pesca. Esse e os outros que não constam do Banco Federativo podem ser encontrados no Pólis (www.polis.org.br/publicacoes/dicas).

Embora o boletim Dicas tenha sido sempre bem recebido, uma das dificuldades era captar novas experiências. Os Dicas eram produzidos a partir da iniciativa de gestores que, na maior parte das vezes, participam das redes em que o Pólis está inserido. Assim, várias iniciativas permaneciam desconhecidas, pela ausência dos gestores e técnicos nessas redes e pela dificuldade dos gestores registrarem suas experiências. Dificuldade real, porque, além da falta de pessoal e da escassez de recursos, os esforços voltam-se para o atendimento à demanda da sociedade. Sem o registro, com o final da gestão municipal e com a dispersão da equipe, perdiam-se da memória as realizações e dificuldades daqueles quatro anos, e, nessa perda, um saber valioso para o aprofundamento democrático esfarelava-se.

Em 1996, a Escola de Administração de Empresas de São Paulo da Fundação 
Getulio Vargas - FGV-EAESP -, em uma iniciativa conjunta com a Fundação Ford - atualmente, com o apoio do BNDES -, criou o Programa Gestão Pública e Cidadania-GPC - (http://inovando.fgvsp.br), que possui um comitê técnico com representantes de diversas instituições, garantindo um alcance e uma representatividade de diversos problemas/soluções nacionais. Por meio de um ciclo de premiação anual, o GPC dá visibilidade às inovações de governos sub-nacionais - municípios, estados e organizações próprias dos povos indígenas - a fim de disseminar essas experiências. Mais importante que o prêmio, embora ele permita dar visibilidade para que a gestão conquiste apoios, é a garantia de que os governos sub-nacionais registrem e divulguem suas experiências. Esse é o insumo para a formação de um banco de dados que já conta com mais de 5 mil experiências. Nele encontramos uma enorme biblioteca ativa, com diferentes saberes em ação nas mais distintas realidades brasileiras - fonte de informação essencial para quem quer trabalhar seriamente com os desafios de um Brasil democrático.

O programa GPC e os Dicas formam, com outras organizações, a Rede de Bancos de Dados em Gestão Local (www.web-brazil.com/gestaolocal), que permite acessar diversas experiências inovadoras. Nessa Rede encontramos insumos para refletir e promover práticas democráticas de gestão pública. É diferente de modelos tradicionais de reflexão acadêmica, que partem de realidades alienígenas para pensar o desenvolvimento local ou de grandes idéias desprovidas de pertinência real que, apesar das boas intenções, quase sempre esbarram nas impossibilidades do real. A Rede de Gestão Local oferece exemplos de práticas que estão sendo efetivadas e permitem construir novas formulações teóricas, amparadas na prática, que contribuam para a melhoria da qualidade de vida de todos, por meio de um
Estado que promova o público como o espaço em que diferentes interesses possam se encontrar. A partir da realidade, das práticas possíveis, podemos pensar e promover a democracia, aí sim, expandindo as possibilidades da realidade atual.

Esse é o desafio que Spink, Bava e Paulics propuseram aos autores dos textos da coletânea Novos Contornos da Gestão Local: partir das experiências para formular novos conceitos para novas práticas. A coletânea é um instrumento de formação que relaciona as experiências inovadoras com os resultados que podem ser almejados e, também, de compreensão do arcabouço institucional que há por trás das experiências inovadoras, buscando explicitar o que propicia condições para as iniciativas surgirem, para se consolidarem e se disseminarem.

Inicialmente publicados como textos isolados - "cadernos arco-íris" -, eles foram organizados em uma única publicação para facilitar a consulta. Nessa caminhada, o GPC e o Pólis contaram com diversos apoios, especialmente do Banco Interamericano de Desenvolvimento - BID - e da Agência Sueca de Cooperação Internacional para o Desenvolvimento - Asdi - para a confecção da coletânea.

Algumas perguntas deram rumo aos artigos e ilustram o conteúdo dos textos. A fim de contribuir para o esclarecimento de inúmeros termos utilizados, Chico de Oliveira procura conceituar desenvolvimento local - "Aproximações ao enigma”. Que tipo de ações um governo local pode implementar para favorecer o desenvolvimento? Até que ponto as decisões das prefeituras, isoladas de uma articulação maior, podem definir esse desenvolvimento? Essas são questões contempladas nos textos de Evelyn Levy - "Ganhar e ganhar" -, de Maria do Carmo Cruz - "Consórcios intermunicipais" - e de Caio Silveira, Cunca Bocayuva e Tania Zapata "Ações integradas e desenvolvimento local". O que tornam efetivas as parcerias nos casos estudados? O que significa estabelecer parcerias que não sejam apenas para "inglês ver" (como Spink brinca)? Diferenciando diversos vínculos existentes, Spink propõe um modo para a compreensão dos vínculos que o Estado estabelece - "Parcerias e alianças com organizações não-estatais".

Analisando como o incentivo às instâncias de participação popular - como Conselhos e OP - pode favorecer a democratização das decisões do governo e a possibilidade de continuidade das políticas, Bava elabora seu texto - "Participação, representação e novas formas de diálogo público". Nessa direção, encontramos a análise sobre a importância da transparência nos governos locais no artigo de José Carlos Vaz - "Desafios para a incorporação da transparência em um modelo de gestão municipal". Explorando como se efetiva a gestão de serviços municipais, temos o texto de Ladislau Dowbor - "A comunidade inteligente". E, no texto escrito pela equipe da Agende, encontramos reflexões sobre eqüidade de gênero nas políticas - "Considerando as diferenças de gênero". O desafio de medir os resultados e definir quais resultados mensurar para identificar as iniciativas importantes ao desenvolvimento sustentável foi assumido por Jorge Kayano e Eduardo Caldas - "Indicadores para o diálogo" -, no último texto da coletânea.

Novos Contornos é, além de uma coletânea de ótimos textos, um marco para aqueles que trabalham na Rede de Gestão Local e para quem acredita que uma boa construção conceitual é fundamental para a compreensão da realidade e, mais que isso, para que políticas que procuram ampliar as possibilidades do real sejam efetivadas. É leitura essencial para gestores e agentes públicos, lideranças locais, docentes e pesquisadores, e para todos os interessados e comprometidos em promover avanços democráticos no Brasil. 